\title{
Local outbreak of the spruce needle tortricid Epinotia tedella Clerk (Lepidoptera, Tortricidae) in the Sudetes in Poland
}

\author{
M. Kosibowicz, W. Grodzki, M. Jachym
}

Forest Research Institute, Department of Mountain Forestry, ul. Fredry 39, 30-605 Kraków, Poland, E-mail: M.Kosibowicz@ibles.waw.pl;W.Grodzki@ibles.waw.pl;M.Jachym@ibles.waw.pl

\begin{abstract}
Kosibowicz M., Grodzki W., Jachym M. 2014: Local outbreak of the spruce needle tortricid Epinotia tedella Clerk (Lepidoptera, Tortricidae) in the Sudetes in Poland. - Beskydy, 7 (1): 29-38

In 2004-2006 a local outbreak of Epinotia tedella was recorded on an area of 1,371 ha in Middle and Eastern Sudetes (Sowie and Bialskie Mts.) in Poland. In Bialskie Mts. slight damage dominated, while in Sowie Mts. more concentrated but moderate damage prevailed. The damage on older trees was limited to the lower half of the crowns, while on younger trees the middle parts of the crowns were more affected. The results of one-year field experiments towards the development of monitoring and forecast tools are presented in the paper. The results from ground emergence traps reflected phenology of butterflies' emergence and the species preferences regarding older stands. The pheromone traps demonstrated the insect concentration on higher (above $900 \mathrm{~m}$ a.s.l.) elevations and confirmed the preference of older stands. Field observations revealed that a part of caterpillars can overwinter in the feeding places in tree crowns. The outbreak was incidental, with no effect on trees and stands. No new damage was recorded after 2006. The use of emergence traps and pheromone traps can be an interesting perspective, but further experiments concerning the interpretation of results are needed.
\end{abstract}

Keywords: Epinotia tedella, Picea abies, monitoring, pheromone traps, Sudetes

\section{Introduction}

Epinotia tedella Clerk is a moth of the family Tortricidae, widespread in Europe, which larvae feed on the needles of Norway spruce Picea abies (L.) Karst., producing short-term (2-3 years) outbreaks (Novák et al. 1975, Führer 1978). First documented outbreaks took place in Czechia and Silesia in 1939-41 and in 1947 (Kalandra 1943, 1948), next in Austrian Alps in 1948-50 (Kurir 1954) and again in Austria in 1956-58 (Maisner 1964). The local heavy damage was recorded in Westfalia in 1950-ties (Ohnesorge 1957a, 1957b). During the outbreaks in northern Germany in 1961-62 and in Czechoslovakia in 1963-64 the insect was subjected to chemical control (Führer 1964a, 1964b, Šrot 1975). In 1960-61 mass damage was recorded in Denmark
(Münster-Swendsen 1979a, 1979b) and in 19691971 in spruce cultures in Belgium, where the trees completely regenerated 1 year after the damage (Baurant, Offergeld 1972). The species is also supposed to be an indicator of industrial air pollutants (Sierpiński 1984).

There are no original publications on E. tedella in Polish literature - the descriptions of the species can be found only in textbooks or atlases (Kiełczewski et al. 1967, Nunberg 1964, Koehler 1981, Schnaider 1991), which indicates that this insect was not of major importance for forests and mass outbreaks on larger areas were not recorded in our country.

In 2004-2006 a local outbreak of E. tedella was recorded in the eastern part of the Sudetes in Poland. The field survey from 2005 revealed the infestation on Norway spruces on an area 
of 1,371 ha, however the damage level was diverse, reaching $10-60 \%$ on the majority of this area in Sowie Mts. (1,115 ha) and Bialskie Mts. (256 ha). Dispersed damage was recorded also in Bystrzyckie Mts., Karkonosze Mts., Izerskie Mts. and Stołowe Mts. It can be pointed out that in the attacked stands a complex of defoliating insects, such as Argyresthia sp., Pachynematus scutellatus (Htg.), Cephalcia spp. contributed to general damage level assessed on spruces.

The aim of the study was to define the importance of the pest and to describe some features of E. tedella occurrence during this outbreak in order to propose methods useful for the assessment and forecast of its population dynamics in the stands.

\section{Materials and methods}

The research was done in the Norway spruce stands in Sowie $\left(50^{\circ} 40^{\prime} \mathrm{N}, 16^{\circ} 29^{\prime} \mathrm{E}\right)$ and Bialskie ( $\left.50^{\circ} 14^{\prime} \mathrm{N}, 16^{\circ} 56^{\prime} \mathrm{E}\right)$ Mts. in Middle and Eastern Sudetes (Fig. 1), where the signs of E. tedella feeding were recorded.

In 2005 the damage in attacked stands was assessed according to the standard procedures applied in the State Forests in Poland, on the level of individual sub-compartments (Instruction of Forest Protection 2004) The following defoliation classes were used: no or weak (0-10\%), slight (11-30\%), moderate (31-60\%), heavy (6190\%) in both areas (Borecki, Keczyński 1992).

The main part of field observations was done during the growing season in 2006. In the early spring the ground emergence traps covering $0.2 \mathrm{~m}^{2}$ of surface were installed in Sowie Mts. under the most attacked trees in order to collect the butterflies emerging from the pupae in the litter.

At the end of May 2006 a set of pheromone traps, covering the area of damaged stands, was installed in Sowie and Bialskie Mts. in order to monitor the spring flight of butterflies. The traps of unitrap type with and insecticide inside, baited with the commercial lure Rhyodor (Chemipan, Poland), usually used for the monitoring of tortricids Rhyacionia buoliana (Schiff.) and Zeiraphera griseana (Hb.), were applied. The traps were installed at about $2 \mathrm{~m}$ above the ground. The bioactive compound of the lures was E-9-dodecenylacetat (0.4 $\mathrm{mg}$ per dispenser), known as a synthetic analogue of the pheromone produced by E. tedella females (Priesner et al. 1989, Pencheva et al. 1998). The set in Sowie Mts. contained 19 traps installed in the most damaged stands, while in Bialskie Mts. 10 traps organized in 3 groups were located in the stands with dispersed species distribution, where the defoliation was caused also by Argyresthia sp. In both areas the traps were installed on southern

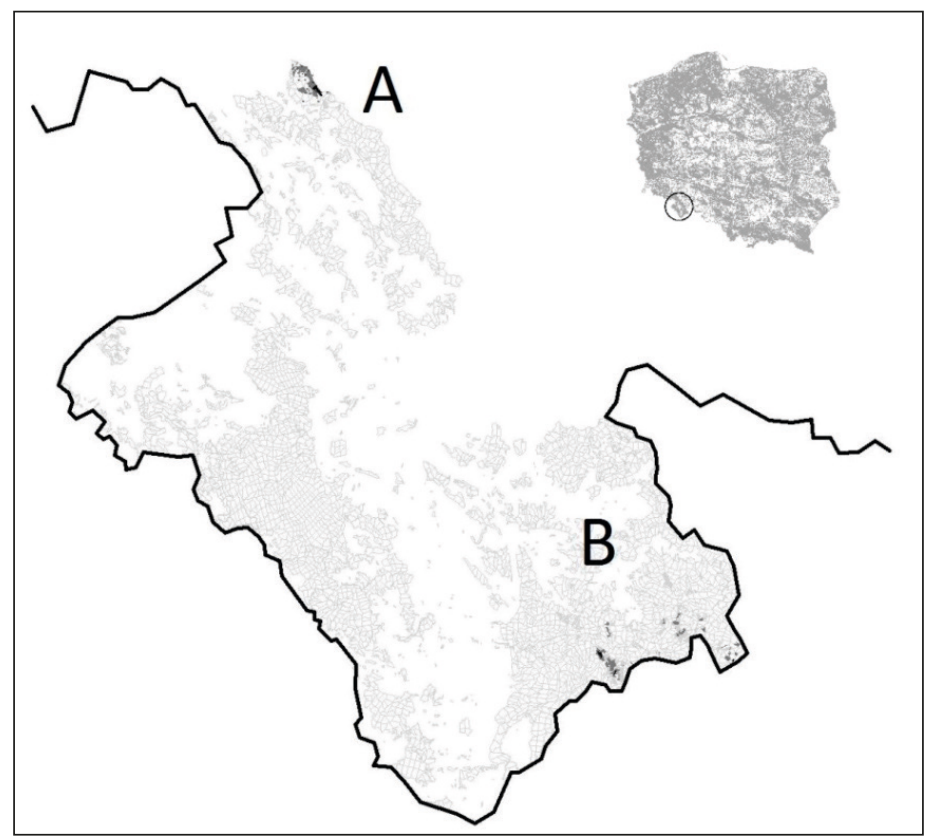

Fig. 1: Location of E. tedella damage in Middle and Eastern Sudetes: A -Sowie Mts., B-Bialskie Mts. 
and south-eastern expositions, in a range of elevations between 700 and 1,000 $\mathrm{m}$ a.s.l. The traps were checked in May and June in order to define the timing of flight and abundance of butterflies caught. In Sowie Mts. the air temperatures during trapping were recorded using the logger Tiny Tag Extra (Gemini) in order to define the effect on swarming.

In July 2006 in the damaged stands in Sowie Mts. the 1-m long branch samples were taken from four felled 90-years old Norway spruce tree in order to define the distribution of the feed nests in the crown profile: the samples $(20$ in total)were taken at 10, 14, 18, 22 and $25 \mathrm{~m}$ above the ground level. Four branch samples were also taken from the middle part of 40-years old spruce tree in order to assess the infestation intensity. The number of needles damaged by one caterpillar in a nest was counted on each sampled branch. The field observations concerning the biology of E. tedella were done during the whole period of investigations.

For testing of differences in the data concerning captures to pheromone traps Kruskal-Wallis test was used. Statistica 9 (Statsoft 2009) software was used for data treatment.

\section{Results}

The level of damage in two mountain areas, assessed in 2005, was different (Fig. 2). The area of attacked stands (understood as the sum of forest sub-compartments' area) was larger in Bialskie
Mts. (1,115 ha), where slight damage dominated (831.3 ha - 75\%), while in Sowie Mts. the damage was more concentrated (256 ha), but with moderate damage (193.14 ha - 75\%) prevailing. The large area in Bialskie Mts. could partially result from the feeding of Argyresthia sp., contributing in defoliation. The percentage of heavily damaged stands was very low in both areas.

In May 2006 no feeding signs were found in Bialskie Mts., while in Sowie Mts. the mosaic damage of diversified intensity was observed on southern and south-western slopes of the mount Wielka Sowa (1,015 $\mathrm{m}$ a.s.l.). The feed nests were located mainly in the lower parts of crowns of middle-age and older stands.

The analysis of branch samples taken from older (90 years) tree revealed the occurrence of feed nests in the lower half of crown and its lack in the upper half (Fig. 3): the higher (mean \pm SD) number of nests $(44.75 \pm 11.12)$ was found at $14 \mathrm{~m}$ and slightly lower $(38.75 \pm 13.15)$ at $18 \mathrm{~m}$. The number of nests in the middle part of the crown of 40-years spruce was similar $(40 \pm 23.08)$, but more diversified (21-73 nests) between sample branches (Tab. 1).

The swarming of E. tedella took place in JuneJuly. During the day the butterflies were sitting on the branches in tree crowns, especially on stand edges. The females lay eggs individually, on the upper surface of last-tear needles. After two weeks the emerged caterpillars start to bore the mines inside the needles, then spin forming

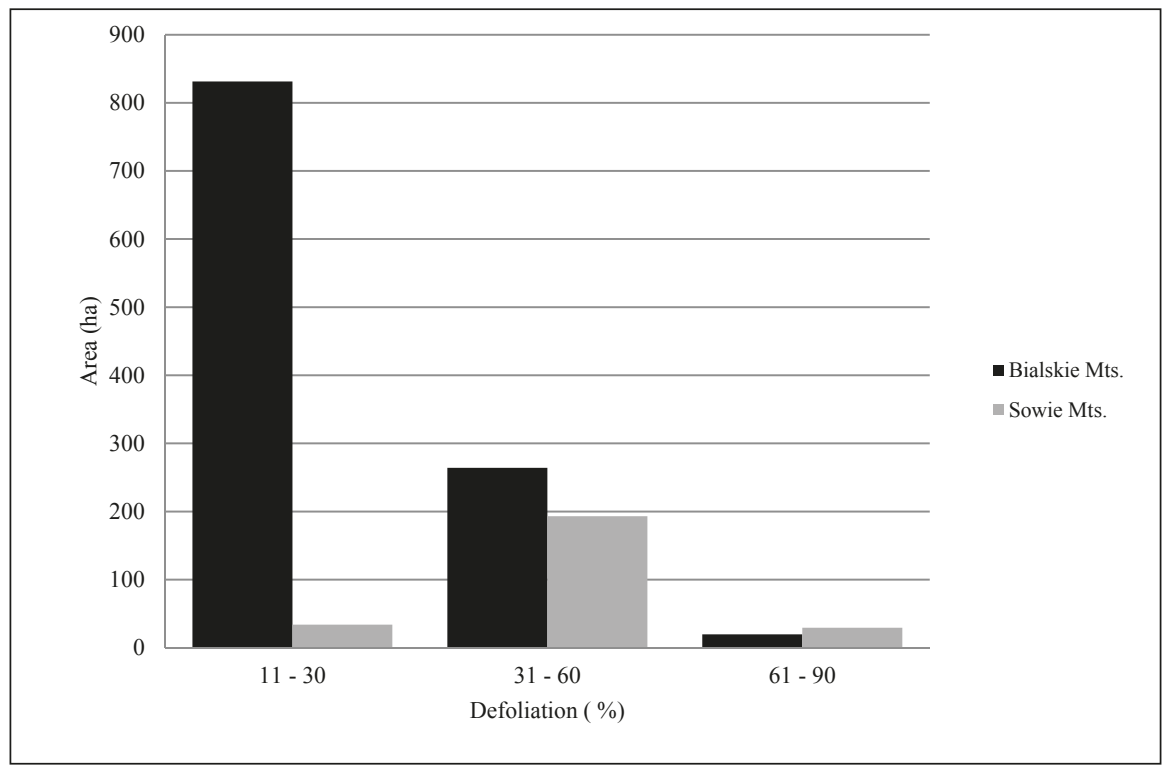

Fig. 2: Area (ha) of stands in individual classes of defoliation caused by Epinotia tedella in Sowie and Bialskie Mts, recorded in 2005. 


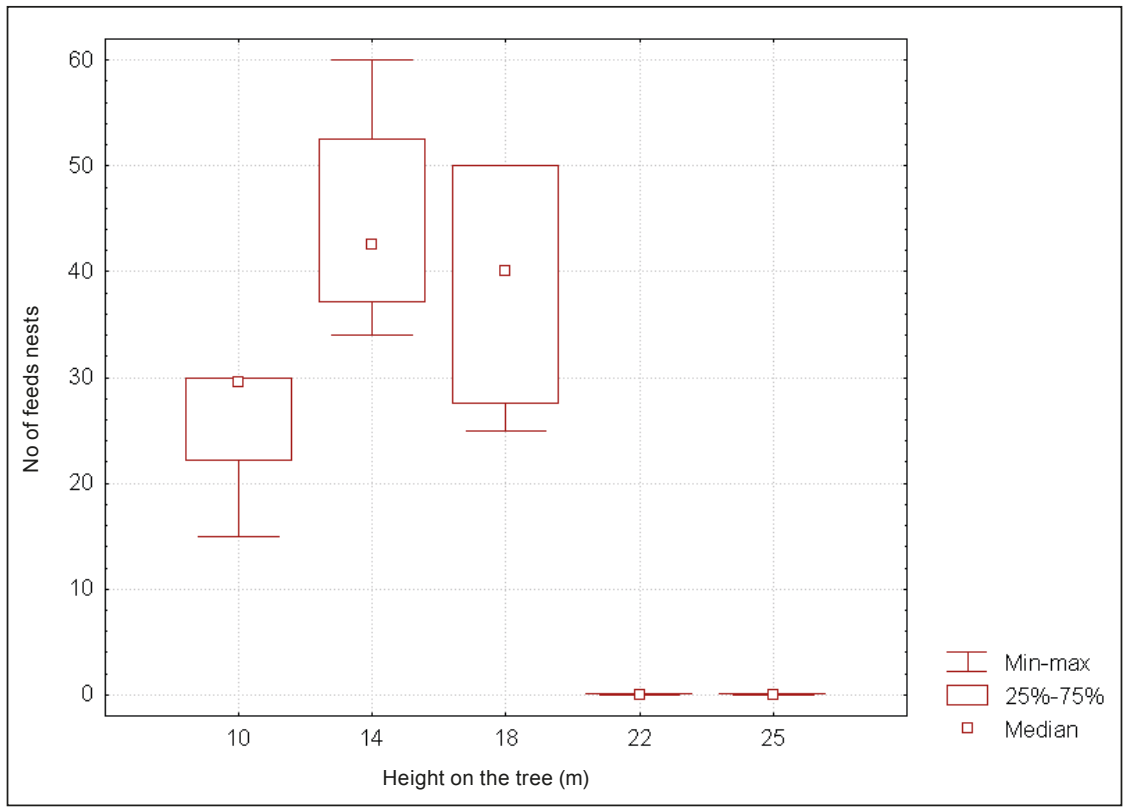

Fig. 3: Number of last-year feed nests of E. tedella on four branches sampled from different parts of 90-years old Norway spruce crown in Sowie Mts.

Tab. 1: Number of last-year feed nests of E. tedella on four branches sampled from the middle part of 40-years old Norway spruce crown in Sowie Mts.

\begin{tabular}{cccc}
\hline Sample & Branch length [cm] & Branch width [cm] & Number of nests / $\mathbf{m}$ of branch \\
\hline 1 & 100 & 60 & 73 \\
2 & 110 & 55 & 38 \\
3 & 100 & 50 & 21 \\
4 & 120 & 60 & 28 \\
\hline
\end{tabular}

a characteristic nest and feed inside till October. One caterpillar can damage till 40 spruce needles. Before the winter the larvae fall on the silk to the litter, where usually overwinter.

The field observations in Sowie Mts. revealed, that the larvae can overwinter and pupate also in the feeding place in the tree crown. This observation was confirmed by the laboratory rearing of the branches sampled at the end of May 2006, from which some butterflies were obtained. This means that a part of caterpillars do not leave the feeding place in autumn, but overwinters there, then pupate and emerge next spring. The first emerged butterflies appeared in the stands just below the mount Wielka Sowa on 22 May 2006.

The first butterflies emerging from the litter appeared in ground emergence traps in the second half of June 2006. The duration of the emergence of adults was relatively short, till the first days of July, with the culmination in the last days of June (Fig. 4). The number of butterflies collected in the emergence traps installed under the canopy of mature stand was 89 , i.e. 445 butterflies per $1 \mathrm{~m}^{2}$, while in the pole stage stand these numbers were much lower - 24 and 120 , respectively. The most intense emergence of butterflies took place in the period of higher mean daily temperatures, which indicates the effect of favorable thermal conditions on the swarming.

The total number of E. tedella adults captured to 29 traps was 302: 190 to 19 traps in Sowie Mts., and 112 to 10 traps Bialskie Mts., but in some (5) traps 0-1 specimens were found. The mean $( \pm S D)$ number of butterflies captured to 1 trap was similar in both areas: $10.05( \pm 15.20)$ and $11.20( \pm 15.42)$, respectively, with no statistically significant differences (Kruskal-Wallis test, $H(\mathrm{df}=1, \mathrm{~N}=29)=0.154, p>0.05$ ), thus pooled data from both areas were used for further analysis. 


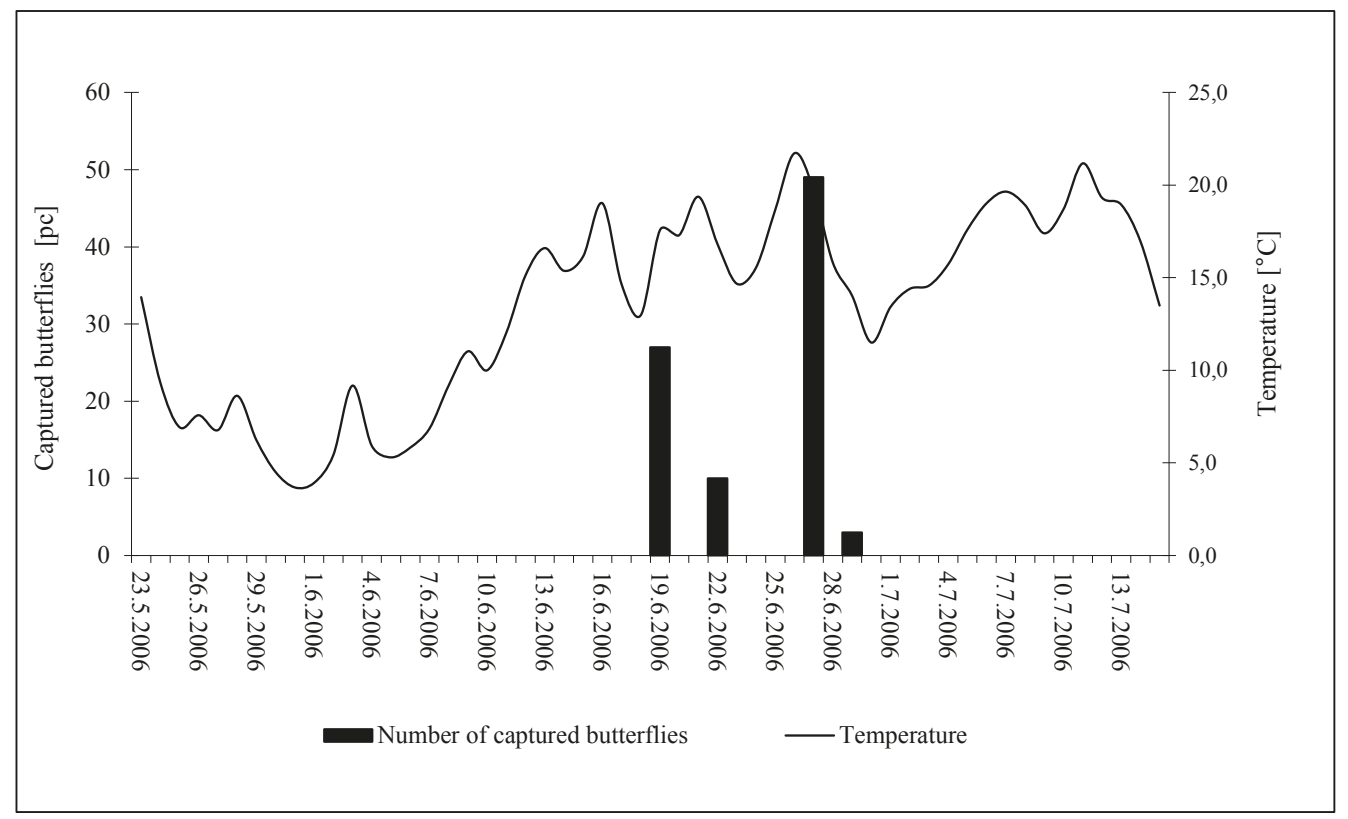

Fig. 4: Number of E. tedella adults collected in ground emergence traps and mean daily temperatures in Sowie Mts. in 2006.

The number of butterflies caught in one trap increased with the increase of altitude, but did not differ significantly in the elevation zones (Kruskal-Wallis test $H(\mathrm{df}=2, \quad \mathrm{~N}=29)=5.851$; $p>0.05)$. The mean captures were the highest in the zone above $900 \mathrm{~m}$ a.s.l. - 14.05 ( \pm 17.49 ), vs. $1.75( \pm 0.50)$ in the zone below $800 \mathrm{~m}$ a.s.l. (Fig. 5).

The captures varied upon the age of stands, which effect was not statistically significant (Kruskal-Wallis test $H(\mathrm{df}=3, \quad \mathrm{~N}=29)=7.509$; $p>0.05$ ). The highest number of butterflies (Fig. 6) was captured in the oldest ( $>90$ years) stands - 15.73 ( \pm 18.21$)$ vs. $2.00( \pm 1.22)$ in the youngest ( $<40$ years) ones. However, the traps with the highest captures were often located in the proximity of young stands or even plantations.

Analyzing the captures in relation to the damage to spruces, recorded in precedent year (2005) no clear pattern was found (Fig. 7) - the captures were similar in all defoliation classes. Higher numbers of butterflies were captured in the stands damaged more than $10 \%$, although the differences were not statistically significant.

In October 2006 no or very few new damage caused by E. tedella was recorded in observed stands. Only single nests were found on young spruces in the understorey. After 2006 no signs of species feeding were recorded in the whole area of Sudetes.

\section{Discussion}

Epinotia tedella can be a serious pest of spruce stands in case of longer outbreaks and/or heavy defoliation (Führer 1964), although usually, due to late (summer/autumn) feeding on last-year needles and no injury to buds, the importance of damage is not high. In addition, the outbreaks are usually short in time (e.g. Kalandra 1943, Maisner 1964, Šrot 1975), which contributes to their lower impact on stands. The feed nests last on the branches for a quite long time, thus one can suppose that the outbreak in Sowie and Bialskie Mts. started probably 2-3 years earlier and our observations were done at the moment of its collapse. From this point of view this outbreak can be assessed as typical for the studied pest.

During the outbreak in Germany it was observed that the activity of butterflies depends on temperatures and insolation, and the eggs were laid in the upper parts of the crowns in young stands of high density, although in older stands the majority of eggs was found in the lower parts of the crowns (Führer 1963), which represents the same pattern as found in our research.

Führer (1964a, b) proposed the critical numbers for E. tedella, reaching the level of 60-70 caterpillars per $1 \mathrm{~m}$ of branch. Supposing that each last-year feed nest was produced by 1 caterpillar we can assess that the populations in our area of interest were slightly below the critical level, which resulted in mainly moderate level of damage, as well as short outbreak duration. 


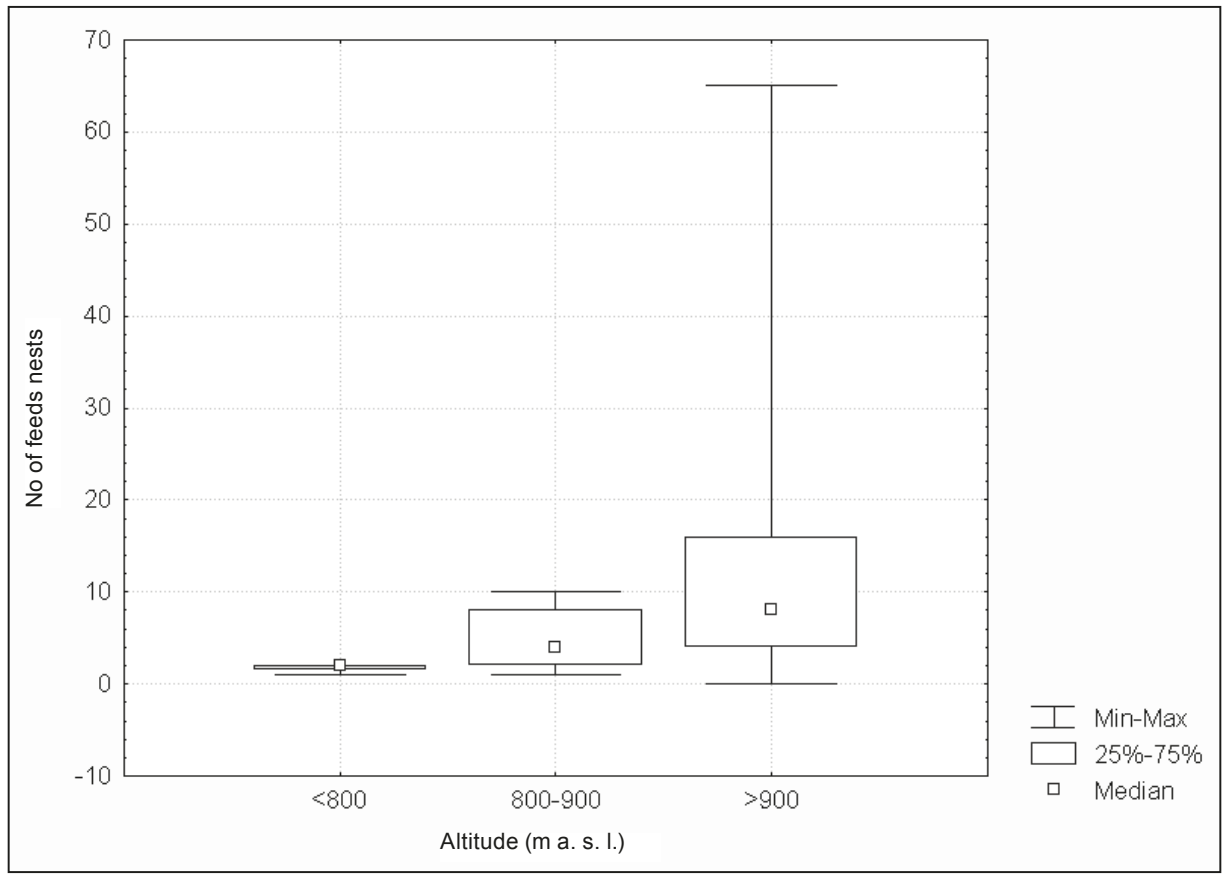

Fig. 5: Captures of E. tedella butterflies per pheromone trap related to elevation zones in Sowie and Bialskie Mts. in 2006.

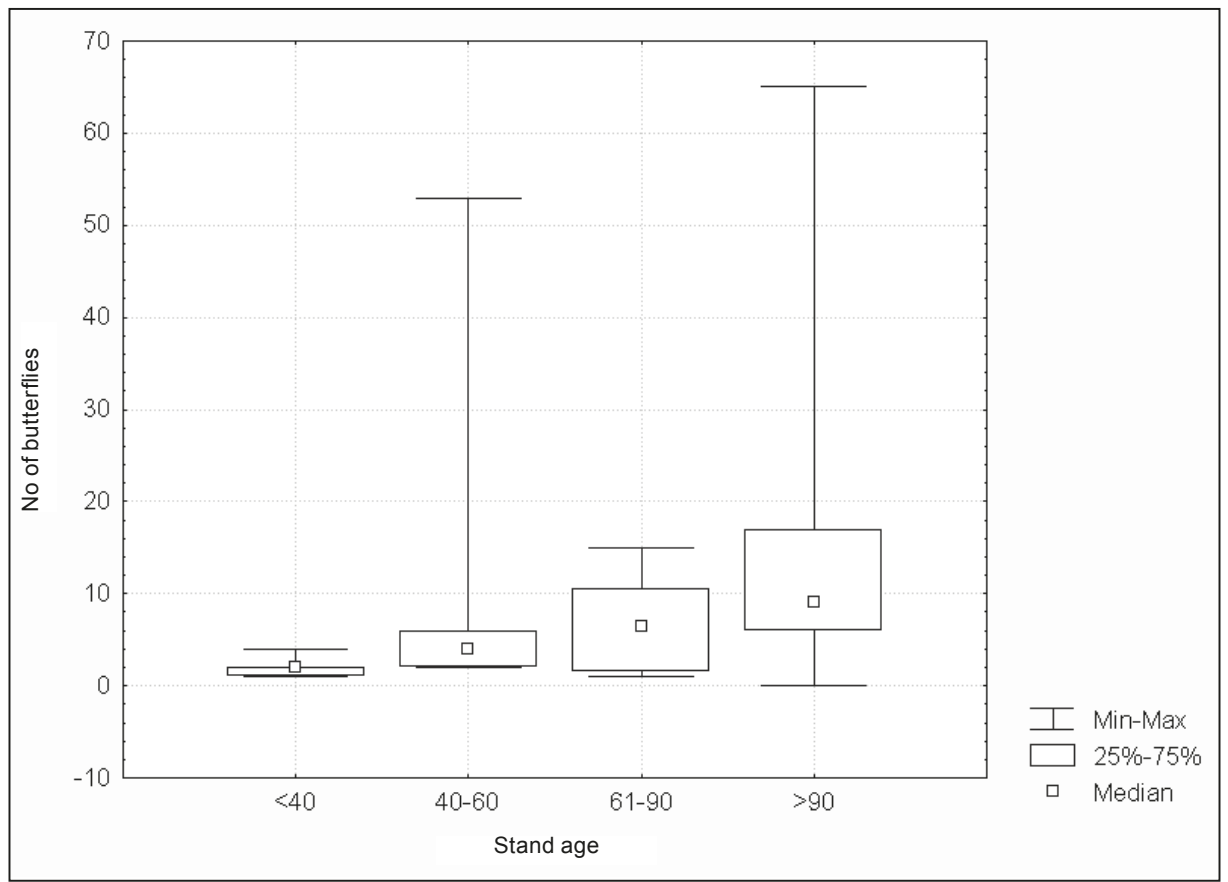

Fig. 6: Captures of E. tedella butterflies per pheromone trap related to the age of stands in Sowie and Bialskie Mts. in 2006. 


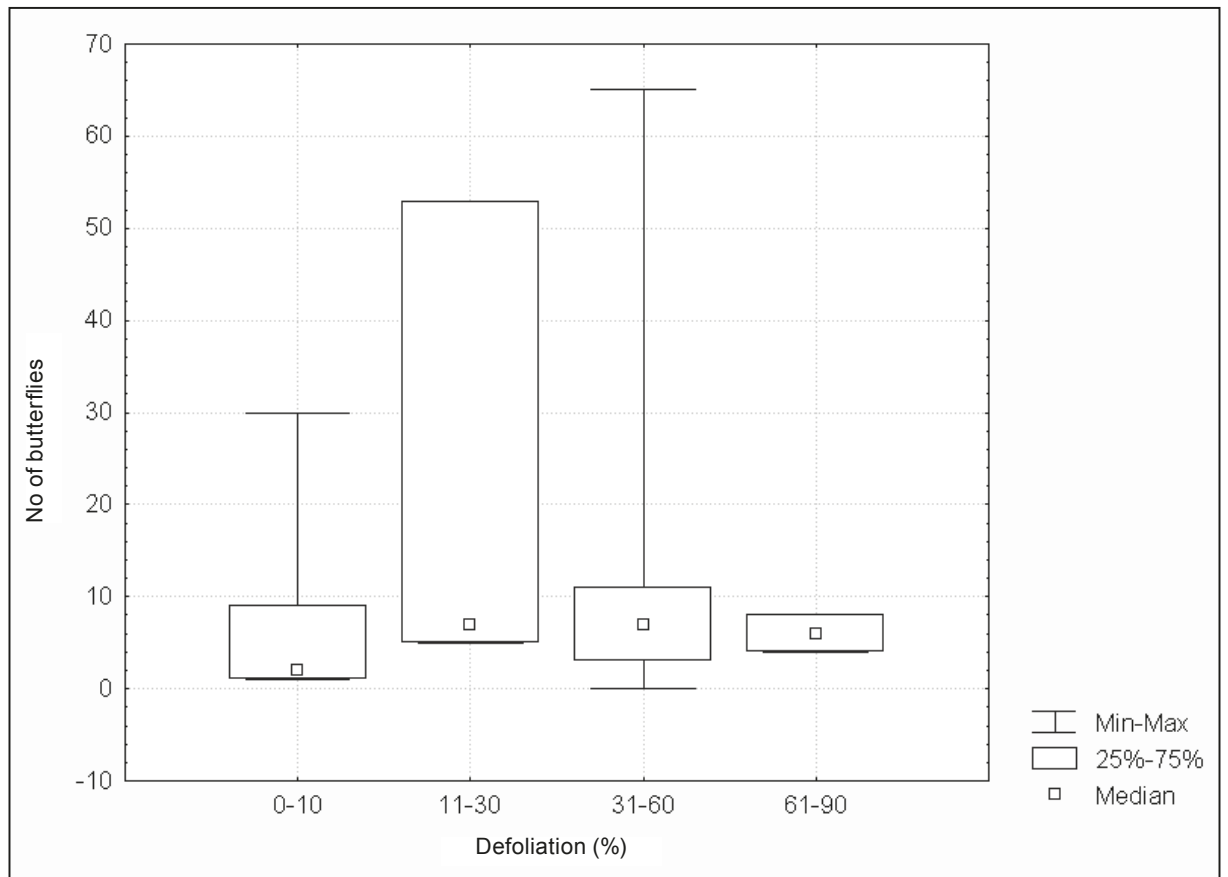

Fig. 7: Captures of E. tedella butterflies to pheromone traps related to the last-year damage recorded in the stands in Sowie and Bialskie Mts. in 2006.

According to the determination key by Beiger (2004), the number of needles usually damaged by one caterpillar is about 10-16. Our observations showed that this number is up to 40 , similar to this reported by Ohnesorge (1957) and probably more realistic in forest conditions. Our observation about the overwintering of a part of caterpillars in the feeding place is quite new, as according to the literature the population overwinters in the litter.

Our one-year field observations in the Sudetes provided a confirmation of some behavioral traits of this species known from Poland (Szujecki 1995). This concerns especially the timing of the spring swarming of butterflies. However, our observation concerning overwintering of E. tedella in as caterpillar in the feeding place seems to be quite interesting. Such overwintering mode is known in another Epinotia species, namely in E. nanana (Treitschke) (Daviault, Ducharme 1966). As the specimens of this species were not found in our material this suggests that the overwintering in caterpillar stage can occur in E. tedella too.

Ohnesorge (1957b) stated that imminent damage to spruce by E. tedella can be forecast while the insect is in the egg or early larval stage, using the population density of the insect, the quantity of food eaten by a single larva and the available food-supply. At present it is the only suggested forecast method. Our experiments with the use of ground emergence traps suggest their usefulness mainly for the phenological survey, however the variability upon stand age indicate that it could be a possible issue too. According to FÜHRER (1978) the forecast of the damage based on the number of swarming butterflies, laid eggs or emerged caterpillars. Taking into consideration that many, already recognized, factors can interfere in the relationships between those figures and later damage we should state that the ground eclectors could be useful mainly for the phonological survey, and the pheromone traps - for the definition of spatial distribution of the species in studied area.

Similarly the trials with the use of pheromone traps, confirming somehow the preferences of the species in relation to stand age and site elevation, but - unfortunately - not spatially correlated with the damage recorded in the last year, suggest possible way to follow. The ultimate condition enabling the use of both methods is the definition of criteria for the interpretation of results, which needs additional field experiments.

The outbreak of E. tedella in Sudetes did not produce any economic effects. The affected stands are regularly damaged by abiotic factors 
(wind, snow), which results in the decrease in their density and some improvement of environmental conditions towards requirements of insect pests. The outbreak - as usually in case of this species - was short in time and (till present) incidental. Nevertheless it was an opportunity for some observations and experiments presented in this article, which can contribute to better recognition of this forest pest.

Analyzing existing publications concerning E. tedella one can remark that most of authors focused on its biology and ecology, but the investigations on the patterns of this species occurrence in altitudinal aspect or in relation to the characteristics of attacked stands were missing. Thus, our paper can be a contribution to the understanding of the environmental preferences of E.tedella, as an important aspect of this species ecology. It should be taken into consideration that during our research the scale of this pest occurrence in mountain stands was the largest in recorded history, thus this local outbreak needs to be recorded.

\section{Conclusions}

Epinotia tedella is a species widespread in Europe, living on spruces in wide age spectrum and causing short-term outbreaks, especially in the stands stressed by another biotic and abiotic agents.

The outbreak in Middle and Eastern Sudetes in Poland, recorded in 2004-2006, was incidental and typical for this species: short in time, with no or negligible effects on trees and stands.

The biological features of the species, observed in the Sudetes, are generally similar to those known from earlier publications. The overwintering of a part of caterpillars in the tree crowns can be considered as a new finding.

The ground emergence traps and pheromone traps could be applied for the monitoring and forecast of E. tedella populations upon the condition of the definition of criteria enabling the interpretation of results, which needs further experiments.

Taking into account the timing and effects of the outbreaks, there is usually no need of control of this pest in managed spruce stands.

\section{Acknowledgement}

The presented research was done within a project 16-U-17 financed by General Directorate of State Forests in Warsaw. The authors thank the administration and field personnel of State Forests for their support in the research.

\section{References}

Baurant, R., Offergeld J.-P. 1972: Observations sur un ravageur forestier: La tordeuse des aiguilles de l'épicéa; Epiblema tedella $\mathrm{Cl}$. [Observations on a forest pest: Epiblema tedella.]. Bulletin de la Société Royale Forestière de Belgique, 79 (11): 529-547.

Beiger, M. 2004: Owady minujace Polski [Insects miners of Poland]. Bogucki Wydawnictwo Naukowe, Poznań, 513 pp.

Borecki, T., Keczyński, A. 1992: Atlas ubytku aparatu asymilacyjnego drzew leśnych [Atlas of forest trees' defoliation]. Generalna Dyrekcja Lasów Państwowych, Agencja Reklamowa „Atut”, Warszawa, 48 pp.

Daviault, L., Ducharme, R. 1966: Life History and Habits of the Green Spruce Leaf Miner, Epinotia nanana (Treitschke) (Lepidoptera: Tortricidae). The Canadian Entomologist, 98(7): 693-699.

FüHrER, E. 1963: Studien über den Fichtennestwickler Epiblema (Epinotia) tedella Cl. in Norddeutschland [Studies on Epiblema (Epinotia) tedella Cl. in Northern Germany]. Anzeiger für Schädlingskunde, Pflanzenschutz, Umweltschutz, 36: 118-124.

FÜHRER, E. 1964a: Über das Massenauftreten von Cl. in Norddeutschland und über einen neuen Schädling an Fichte in Mitteleuropa [On the Epiblema tedella Cl. outbreak in Northern Germany and on the new pest of spruce in Central Europe]. Schriftenreihe Forstlische Fakultät Universität Göttingen, 33: 33-44.

FüHrER, E. 1964b: Zum Auftreten des Fichtennestwicklers Epiblema tedella Cl. (Lep, Tortricidae) in Schleswig-Holstein [On the occurrence of Epiblema tedella Cl. (Lep, Tortricidae) in Schleswig-Holstein]. Zeitschrift für angewandte Entomologie, 54: 150-163.

FÜHRER, E. 1978: Die Gattungen Griselda und Epinotia (Lep., Tortricidae) [Griselda and Epinotia (Lep., Tortricidae)]. In: Schwenke, W. (Hrsg.): Die Forstschädlinge Europas. Bd. III. Paul Parey, Hamburg und Berlin: 134-152.

Instrukcja ochrony lasu [Instruction of forest protection]. Centrum Informacyjne Lasów Państwowych, Warszawa, 271 pp. 
Kalandra, A. 1943: Erfahrungen uber das epidemische Auftreten des Fichtenwicklers Epiblema tedella Cl. in den Jahren 1939-41 [Experiences on the epidemic occurrence of Epiblema tedella Cl. in the years 1939-1941]. Zentralblatt für das gesamte Forstwesen, 69: 18-27.

KalAndrA, A. 1948: Kalamitní škůdci, sucho a požáry v lesích Čech a země Moravskoslezské v r. 1947 [Catastrophic insect outbreaks, drought and fires in the forests of Bohemia and Silesia in 1947]. Lesnická práce, 27(2): 33-38.

KieŁczewski, B., Szmidt, A., KadŁubowsKi, W. 1967: Entomologia leśna z zarysem akarologii [Forest entomology with the outline of acarology]. PWRiL, Warszawa, 661 pp.

KoeHLeR, W. 1981: Zarys hylopatologii [Outline of hylopathology]. PWN, Warszawa, 407 pp.

KurIR, A. 1954: Einige Untersuchungsergebnisse aus der Gradation des Fichtennestwicklers (Epiblema tedella Cl.) in Österreich 1948-1950 [Some results of investigations into the E. tedella epidemic in Austria, 194850]. Zentralblatt für das gesamte Forst- und Holzwirtschaft, 72(2/3): 121-147.

MAisner, N. 1964: Untersuchungen zur bionomie des fichtenandelnestwicklers (Epiblema tedella Cl.) und die sein auftreten begrenzenden Faktoren [The bionomics of Epiblema tedella and the factors limiting its occurrence]. Mitteilungen aus der Forstlichen Bundesversuchsanstalt, Mariabrunn, 65: 49-70.

Münster-Swendsen, M. 1979a: The parasitoid complex of Epinotia tedella (Cl.) (Lepidoptera: Tortricidae). Entomologiske Meddelelser, 47(2): 63-71.

MÜnster-Swendsen, M. 1979b: Betydningen af aggregationsmoenstre for samspillet imellem en vaertsart, Epinotia tedella (Cl.), og dens parasitoidarter [The effect of aggregation patterns on the interference between a host species, Epinotia tedella (Cl.), and its parasitoid species]. Entomologisk Tidskrift, 100(3/4): 145-149.

Novák, V., Hrozinka, F., Starý, B. 1975: Atlas szkodników owadzich drzew leśnych [Atlas of insect pests of forest trees]. PWRiL, Warszawa, 133 pp.

Nunberg, M. 1964: Uszkodzenia drzew i krzewów leśnych wywołane przez owady [Damage to forest trees and shrubs from the insects]. PWN, Warszawa, 573 pp.

Ohnesorge, B.1957a: Die Prognose von Fichtennestwicklerschäden (Epiblema tedella Cl.) [Prediction of damage by E. tedella]. Zeitschrift für Pflanzenkrankheiten, Pflanzenpathologie und Pflanzenschutz, 64(7/10): 550-554.
OHnesorge, B., 1957b: Massenvermehrung von Epiblema tedella Cl. in Norddeutschland [Mass outbreak of E. tedella in N.W. Germany]. Forst-und Holzwirtschaft, 12 (5): 76-77.

Pencheva, A. J., Subchev, M.A., Voerman, S. 1998: Seasonal flight of Epiblema tedella Cl. (Lepidoptera: Tortricidae) - investigations by pheromone traps in Bulgaria. Acta Zoologica Bulgarica, 50(1): 93-97.

Priesner, E., Reed, D.W., Underhill, E.W., BoGENSCHÜTZ, H. 1989: (Z,Z)-7,9-dodecadienyl acetate, sex pheromone of Epinotia tedella Clerck (Lepidoptera: Tortricidae). Journal of Chemical Ecology, 15(10): 2457-2464.

SchnAider, Z. 1991: Atlas uszkodzeń drzew i krzewów powodowanych przez owady i roztocze [Atlas of damage to trees and shrubs caused by insects and mites]. PWN, Warszawa, 317 pp.

SIERPIŃsKI, Z. 1984: Über den Einfluß Luftverunreinigungen auf Schadinsekten in polnischen Nadelbaumbeständen [The effect of air pollution on harmful insects in stands of coniferous trees in Poland]. Forstwissenschaftliches Centralblatt, 103: 83-92.

SzUJECKI, A. 1995: Entomologia leśna [Forest entomology]. Wydawnictwo SGGW, Warszawa: 237-238.

Šrot, M. 1975: Některé poznatky z bionomie obaleče smrkového Epiblema tedella Cl. v ČSR a možnosti boje proti němu [Some data on the bionomics of the spruce leaf roller Epiblema tedella in Bohemia and Moravia and possibilities for its control.] Práce Výzkumného ústavu lesního hospodář́ství a myslivosti, 46: 121-144. 
